\title{
Phenotypic and genetic characterization of indigenous Tswana goats
}

\author{
P.I. Monau ${ }^{1,2}$, C. Visser ${ }^{1}$, S.J. Nsoso ${ }^{2}$ \& E. van Marle-Köster ${ }^{1 \#}$ \\ ${ }^{1}$ Department of Animal and Wildlife Sciences, University of Pretoria, Pretoria 0002, South Africa \\ ${ }^{2}$ Department of Animal Science, Botswana University of Agriculture and Natural Resources, Private Bag 0027, \\ Gaborone, Botswana
}

(Received 5 April 2018; Accepted 6 August 2018; First published online 20 November 2018)

Copyright resides with the authors in terms of the Creative Commons Attribution 4.0 South African Licence.

See: http://creativecommons.org/licenses/by/4.0/za

Condition of use: The user may copy, distribute, transmit and adapt the work, but must recognise the authors and the South African Journal of Animal Science.

\begin{abstract}
Tswana goats that were kept in communal systems in three agro-ecological regions in Botswana were characterized according to phenotypic measurements and genotypic data. Objective measurements for 123 goats included bodyweight (BW), body length (BL), heart girth (HG), height at withers (HW), and tail length (TL), while qualitative traits included coat colour and presence or absence of horns and beards. Age was estimated based on dentition. Hair samples were collected from 48 of the phenotyped animals in the largest region (central region) and genotyped with the Illumina Goat50K SNP chip. Mixed coat colour was predominant and across regions $95 \%$ of the goats were horned and bearded. Goats in the northwest region had the lowest BW and significantly higher HG values in all age groups compared with other regions. Goats over four years old in the central and northwest regions were significantly longer in body compared with the ones from the southern region. The average expected heterozygosity and inbreeding coefficient were 0.423 \pm 0.03 and $0.009 \pm 0.05$, respectively. Principal component analysis clustered most animals, with a few outliers. The effective population size has decreased over time and at 13 generations ago was estimated at 266. There were high genetic and phenotypic variations in the indigenous Tswana goats, which should be exploited to increase performance through within-breed selection and structured crossbreeding.
\end{abstract}

Keywords: Botswana, genomic diversity, morphometric, population size, Single nucleotide polymorphisms \# Corresponding author: Este.vanMarle-Koster@up.ac.za

\section{Introduction}

Characterization of indigenous livestock species is the key to development of proper strategies for long-term maintenance and use of genetic variation, and for guidance in decisions about future utilization and conservation strategies (Msanga et al., 2012). In southern Africa, studies have been conducted to characterize indigenous goats including Mozambican goats (Garrine, 2007), Tanzanian goats (Madubi et al., 2000; Ngulumaet al., 2018), South African goats (Pieters et al., 2009; Mdladla et al., 2016) and Namibian goats (Els et al., 2004). However, the majority of studies have been limited to microsatellite markers and genomic information on local goat characterization in the region remains scarce. The majority of indigenous populations are not managed through herd book registrations (Van Marle-Köster et al., 2015). Although crossbreeding is important for hybrid vigour and breed complementarity, if it is indiscriminate, it poses a threat to most indigenous goat populations as it results in a decline in the adapted traits, ultimately reducing the efforts at improving food security in rural areas (Rischkowsky, et al., 2007).

In Botswana, there are approximately 1.6 million goats. The main indigenous breed is the Tswana goat, which constitutes $71 \%$ of the national goat population (Botswana Agricultural Statistics, 2013). This breed is found in various geographical regions of the country under low-input management systems and contributes significantly to the livelihoods of resource-poor farmers as a source of protein and income (Monau et al., 2017). The Tswana goat is known for its unique adaptive traits such as heat and drought tolerance, and lower disease susceptibility, which make it ideal for production under stressful tropical environments (Katangole et al., 1996; Nsoso et al., 2004). However, it has received little attention in research projects. The last phenotypic characterization studies on Tswana goats were undertaken more than a decade ago (Nsoso et al., 2004), and may not reflect the current situation, because of changes in 
population and in production systems (Solkner et al., 1998). The only previous effort to characterize indigenous Tswana goats at genetic level was done at a research station, using 12 microsatellite markers on a very small population that was under selection (Maletsanake et al., 2013). This population did not represent the variation that occurs in the country, and failed to show inherent genetic variation of the Tswana goat population.

Although the advantages of microsatellites have been well documented (Singh et al., 2014), genomewide single nucleotide polymorphism (SNP) markers provide new possibilities for genetic characterization and biodiversity studies (Blasco \& Toro, 2014). Several SNP assays have been used in the analyses of population diversity and structure of many livestock species (Lin et al., 2010; Kanyile et al., 2015; Makina et al., 2015; Lashmar et al., 2016; Mdladla et al., 2016). The commercial Goat50K SNP panel, which was developed in 2012 (Tosser-Klopp et al., 2014), offers an opportunity for genetic characterization of goats.

The purposes of this study were to phenotypically characterize Tswana goats in three agro-ecological regions of Botswana and to assess the genetic diversity and population structure of this genetic resource in the central region using the Goat50K SNP panel.

\section{Materials and Method}

The use of animals complied with the guidelines approved by the Ethics Committee of Faculty of Natural and Agricultural Sciences at the University of Pretoria (ECO42-15).

The study was carried out in Botswana from December 2015 to March 2016. The climate of the country is mainly semi-arid. Rainfall occurs during the summer months of October to April and is low, unreliable, unevenly distributed, and highly variable from year to year (Makhabu et al., 2002). The highest average temperatures generally occur from October to April and the lowest from May to August. Drought is a recurrent phenomenon, and all rivers in the country are seasonal, except for the Okavango and Linyanti/Chobe rivers in the northwest (Mogotsi et al., 2013). Geographically, soil varies from one region to another, with about two thirds of the country being covered in infertile sandy soils (red and grey desert soils) (Mogotsi et al., 2011). Four agro-ecological regions are distinguished in Botswana, with the southern region being classified as hard veldt, the central region as hard veldt with the dominance of woodland Collospermun mophane trees, the northwest as sand veldt with thick forest, lush green plains and semi-arid shrub savanna trees, and the Ghanzi as sand veldt with shrub savanna trees.

Random sampling was performed to select representative districts, villages and farms, based on knowledge of livestock (particularly goats) from livestock extension officers in each region. In each village, four to five farms were randomly selected and one to five unrelated Tswana goats per farm were measured. To avoid sampling related individuals, farmers stated the origin and familial relationships of individual animals.

Animals were grouped into five age categories based on dentition, namely no pairs of permanent incisors (<14 months), one pair of permanent incisors (15-23 months), two pairs of permanent incisors (2435 months), three pairs of incisors (36-48 months), and four pairs of incisors (over 48 months), according to Pace \& Wakeman (2003). Bodyweight (BW) was measured using a hanging scale. Body length, HG, HW, and TL were measured with a tailor's tape following the standard procedure reported by FAO (2012). Morphological descriptions such as coat colour and presence or absence of horns and beard were also recorded. One hundred and twenty-three goats were measured in total, of which 47, 54 and 22 were located in the southern, central and northwest regions, respectively. No Tswana goats were observed in the Ghanzi region. All goats were kept under extensive systems in communal areas and were not selected for production traits.

Hair samples were collected from forty-eight of the animals in the central region, as this is the largest region $\left(142,302 \mathrm{~km}^{2}\right)$. Hair samples were collected by plucking 50 to 100 hairs from each animal, ensuring intact follicles. The hair samples were kept in labelled envelopes and transported to the University of Pretoria laboratory and then shipped to Animal Genetic Laboratory in France, Labogena DNA platform (Domaine de Vilvert, CS 80009, 78353 Jouy en Josas cedex), for DNA extraction and genotyping.

Procedure frequency was used to analyse qualitative traits and general linear model was used to analyse quantitative traits in Statistical Analysis System (SAS) (SAS Institute, 2009). Owing to low numbers of animals at 0-14 months and 15-23 months, only three age categories were used, that is, 24-35 months, 36-48 months, and above 48 months. Analysis was also confined to females owing to the small number of males (castrates and bucks) that were kept. Fixed effects were considered to significantly affect performance when $P<0.05$. This statistical model was implemented to analyse BW and body measurements:

$$
Y_{i j k}=\mu+\text { age }_{i}+\text { region }_{j}+e_{i j k}
$$

where $Y_{i j k}=$ observation on body measurement 


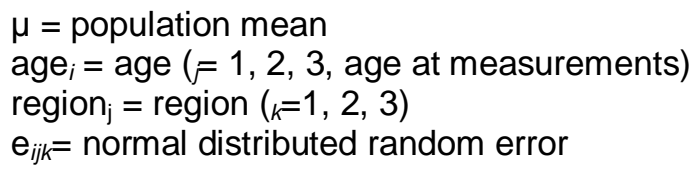

Forty-eight animals from the central region were genotyped using the Illumina Goat50K SNP Bead chip, which contains 53,347 SNPs. Only autosomal SNPs were considered, while SNPS on the sex chromosomes and SNPs with unmapped locations to the latest reference assembly of the goat genome were excluded from the analysis. Plink version 1.07 software (Purcell et al., 2007) was used for analysis. Quality control was performed with these standard thresholds: individual call rate lower than 97\%, SNP call rate less than 97\%, SNPs with MAF below 0.05, and SNPs that deviated significantly from Hardy-Weinberg equilibrium $(P<0.001$ ). After quality control, genetic diversity parameters (observed and expected heterozygosity) and average individual inbreeding coefficient ( $\left.F_{I S}\right)$ across autosomes were calculated using Plink software (Purcell et al., 2007). A Principal component analysis (PCA) was performed using genomewide complex trait analysis (GCTA version 1.24; Yang et al., 2011). ADMIXTURE version 1.23 (Alexander et al., 2009) was used to investigate population differentiation based on SNP genotype data. A crossvalidation $(\mathrm{CV})$ procedure was performed on 48 animals to choose for optimal K-value with the lowest $\mathrm{CV}$ error values.

After quality control, pair-wise linkage disequilibrium (LD) was assessed through the correlation coefficient $\left(r^{2}\right)$ using Plink software (Purcell et al., 2007). The command '-r2 -ld-window-kb $2000-l d-$ window-r2 0' was used to calculate the association among SNP pairs up to a distance of $2000 \mathrm{~kb}$. To inspect the LD decay with physical distance, SNP pairs were sorted into bins based on pair-wise marker distance and the average of each bin was calculated. These bins were defined, namely 0-10, 10-20, 20-40, 40-60, 60-80, 80-100, 100-200, 200-500, 500-1000 and 1000-2000 kb.

Effective population size (Ne) was determined based on $r^{2}$ values at various distances and assuming a model without mutation, as described by Corbin et al. (2010) using SNep version 1.1 (Barbato et al., 2015). Minimum and maximum inter-SNP distances of 0 and $1000 \mathrm{Mb}$, respectively, were used with 30 distance bins of $50 \mathrm{~kb}$ each. Ne estimates were subsequently calculated from $\mathrm{r}^{2}$ values obtained for the average distance of each bin.

\section{Results}

Adult goats dominated the flock structure across regions with 29\% in the 24-35 month age group, $42 \%$ in 36-48 months and 23\% over four years old. The young and grower age groups of 0-14 months and 15-23 months accounted for only $2 \%$ and $4 \%$ of the flocks, respectively. However, the numbers of goats older than 48 months in the southern and northwest regions were significantly $(P<0.05)$ less compared with central region. Across all regions, Tswana female goats were predominant (92\%) (Table 1).

Table 1 Flock structure of indigenous Tswana goats in surveyed regions of Botswana

\begin{tabular}{|c|c|c|c|c|c|}
\hline \multirow{2}{*}{ Parameters } & \multicolumn{3}{|c|}{ Regions } & \multirow{2}{*}{$\begin{array}{l}\text { Overall } \\
\text { Total }\end{array}$} & \multirow{2}{*}{$\begin{array}{c}\text { Overall Percentage } \\
(\%)\end{array}$} \\
\hline & Southern & Central & Northwest & & \\
\hline \multicolumn{6}{|l|}{ Age } \\
\hline 0-14 months & 2 & 0 & 0 & 2 & 2 \\
\hline 15-23 months & 2 & 3 & 0 & 5 & 4 \\
\hline 24-35 months & 13 & 16 & 7 & 36 & 29 \\
\hline 36-48 months & 26 & 17 & 9 & 52 & 42 \\
\hline Over 48 months & $4^{a}$ & $18^{\mathrm{c}}$ & $6^{\mathrm{b}}$ & 28 & 23 \\
\hline \multicolumn{6}{|l|}{ Sex } \\
\hline Intact males & 0 & 1 & 1 & 2 & 2 \\
\hline Females & 43 & 50 & 20 & 113 & 92 \\
\hline Castrated males & 4 & 3 & 1 & 8 & 6 \\
\hline
\end{tabular}

${ }^{a b c}$ Different superscripts within a row differ significantly $(P<0.05)$ 
Almost all goats (95\%) were horned and bearded. Seven coat colours were observed across all regions, with mixed colour (28\%), brown and white (23\%) and black and white (23\%) patterns being the most prominent. Evenly coloured goats, that is, brown, black or white, were less common (Table 2).

Table 2 Qualitative traits of indigenous Tswana goats in various agro-ecological regions of Botswana

\begin{tabular}{|c|c|c|c|c|c|}
\hline \multirow{2}{*}{ Parameters } & \multicolumn{3}{|c|}{ Regions } & \multirow{2}{*}{$\begin{array}{l}\text { Overall } \\
\text { Total }\end{array}$} & \multirow{2}{*}{ Overall Percentage } \\
\hline & Southern & Central & Northwest & & \\
\hline \multicolumn{6}{|l|}{ Coat colour } \\
\hline Mixed colour & 13 & 15 & 6 & 34 & 28 \\
\hline Brown and white & 10 & 13 & 5 & 28 & 23 \\
\hline Black and white & 12 & 12 & 4 & 28 & 23 \\
\hline Brown and black & 7 & 7 & 2 & 16 & 13 \\
\hline Brown & 4 & 3 & 4 & 11 & 9 \\
\hline Black & 1 & 2 & 0 & 3 & 2 \\
\hline White & 0 & 2 & 1 & 3 & 2 \\
\hline \multicolumn{6}{|l|}{ Horn } \\
\hline Horned & 42 & 53 & 22 & 117 & 95 \\
\hline Polled & 5 & 1 & 0 & 6 & 5 \\
\hline \multicolumn{6}{|l|}{ Beard } \\
\hline Presence & 47 & 49 & 21 & 117 & 95 \\
\hline Absence & 0 & 5 & 1 & 6 & 5 \\
\hline
\end{tabular}

Morphological differences were observed between regions, with HW being significantly $(P<0.05)$ lower at 24-35 months in southern region compared with the northwest. Goats in the northwest region had significantly $(P<0.05)$ lower BW and higher HG values at 36-48 months and at $>48$ months. Body length measurement was significantly lower in the southern region compared with central region at over 48 months. The tails of goats from the central region were significantly longer than those from the southern region at over 48 months (Table 3). Most morphological differentiation based on region could be observed in the mature goats, older than four years.

Table 3 Mean ( \pm SE) for bodyweight and body measurements of female Tswana goats

\begin{tabular}{llllcll}
\hline Age & Region & Body weight & Body length & Height at withers & Heart girth & Tail length \\
\hline \multirow{2}{*}{$24-35$} & Southern & $29.3 \pm 0.8$ & $63.3 \pm 1.3$ & $62.1^{\mathrm{a}} \pm 1.1$ & $70.9 \pm 1.3$ & $20.4 \pm 0.7$ \\
months & Central & $30.3 \pm 0.7$ & $63.0 \pm 1.2$ & $63.7^{\mathrm{ab}} \pm 1.0$ & $70.3 \pm 1.2$ & $20.5 \pm 0.7$ \\
& Northwest & $28.2 \pm 1.2$ & $64.0 \pm 2.1$ & $66.4^{\mathrm{b}} \pm 1.7$ & $74.6 \pm 2.1$ & $20.6 \pm 1.2$ \\
\hline \multirow{2}{*}{$36-48$} & Southern & $34.0^{\mathrm{b}} \pm 0.5$ & $67.6 \pm 0.9$ & $65.4 \pm 0.8$ & $72.9^{\mathrm{a}} \pm 0.9$ & $20.3 \pm 0.5$ \\
months & Central & $32.8^{\mathrm{ab}} \pm 0.7$ & $66.7 \pm 1.2$ & $63.8 \pm 1.0$ & $72.7^{\mathrm{a}} \pm 1.2$ & $22.1 \pm 0.7$ \\
& Northwest & $31.2^{\mathrm{ab}} \pm 0.9^{\mathrm{a}}$ & $67.6 \pm 1.5$ & $66.1 \pm 1.3$ & $76.7^{\mathrm{b}} \pm 1.6$ & $20.3 \pm 0.9$ \\
\hline \multirow{2}{*}{$\begin{array}{l}\text { Over 48 } \\
\text { months }\end{array}$} & Southern & $33.8^{\mathrm{ab}} \pm 1.4$ & $64.3^{\mathrm{a}} \pm 2.3$ & $65.8 \pm 2.0$ & $70.8^{\mathrm{a}} \pm 2.3$ & $19.3^{\mathrm{a}} \pm 1.3$ \\
& Central & $34.7^{\mathrm{b}} \pm 0.6$ & $71.8^{\mathrm{b}} \pm 1.1$ & $65.9 \pm 0.9$ & $76.1^{\mathrm{b}} \pm 1.1$ & $22.9^{\mathrm{b}} \pm 0.6^{\mathrm{a}}$ \\
& Northwest & $31.2^{\mathrm{a}} \pm 1.1$ & $69.2^{\mathrm{ab}} \pm 1.9$ & $65.8 \pm 1.6$ & $80.5 \pm 1.9^{\mathrm{c}}$ & $21.0^{\mathrm{ab}} \pm 1.1$ \\
\hline
\end{tabular}

${ }^{\mathrm{ab}}$ Means with different superscripts within a column, age group and trait differ significantly $(P<0.05)$ 
The average genotyping call rate across 48 animals was $99.6 \%$. No individuals were removed. A total of 5203 SNP markers was removed during quality control, namely 2338 because of low call rate $(<0.97)$, 2728 owing to low MAF $(<0.05)$ and 137 markers that violated HWE $(P<0.001)$. This resulted in 44741 SNP markers that were retained for further analysis. The MAF of SNPs followed a uniform distribution across the chromosomes and averaged at $0.32 \pm 0.13$. The average observed and expected heterozygosity was 0.419 \pm 0.02 and $0.423 \pm 0.03$, respectively. The average individual inbreeding coefficient $\left(F_{I S}\right)$ was $0.009 \pm 0.05$.

Breed composition was assessed for the 48 genotypes using a PCA in which most of the animals were clustered, with a few outliers (Figure 1). To investigate whether there was genetic differentiation, an ADMIXTURE version 1.23 (Alexander et al., 2009) was performed and the lowest cross-validation error was at $\mathrm{K}=1$.

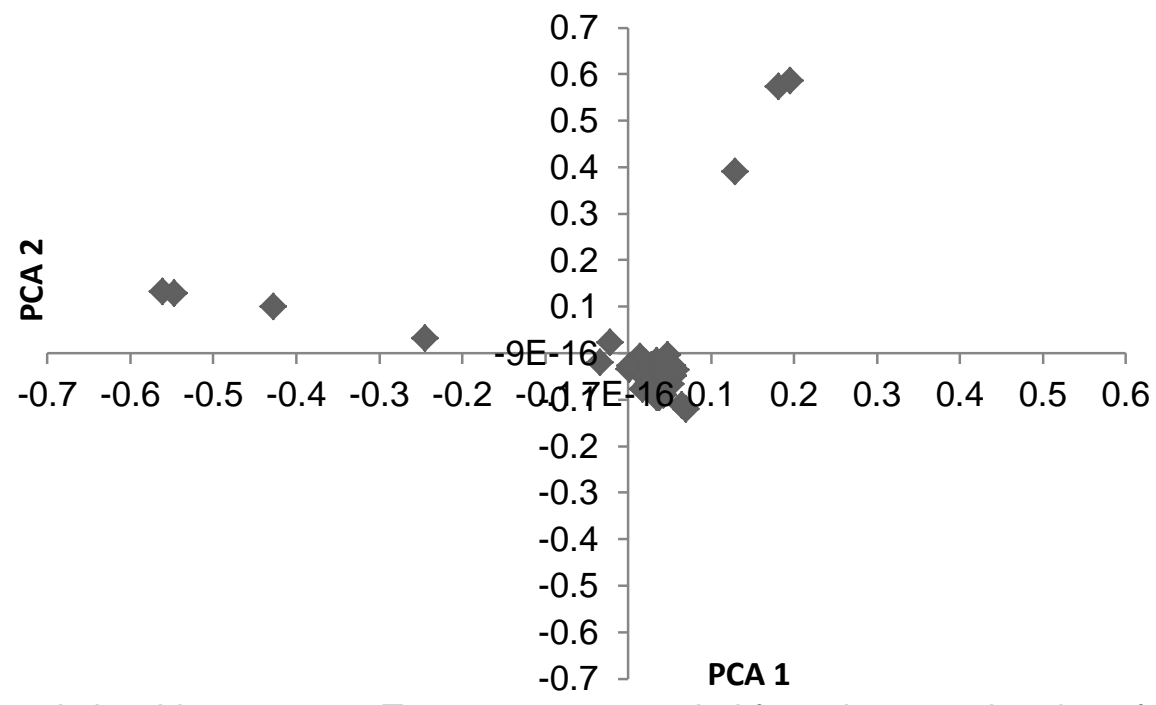

Figure 1 Genetic relationship among 48 Tswana goats sampled from the central region of Botswana (PCA1 vs. PCA2)

PCA: Principal component analysis

The average LD values at given distance intervals for the population are displayed in Figure 2. The highest average $r^{2}$ of 0.44 was observed at $0-10 \mathrm{~kb}$. LD declined with increasing distance between SNP pairs, and the most rapid decline was seen over the first $10 \mathrm{~kb}$. The average ${ }^{2}$ for all pair-wise adjacent SNP autosomes was $0.067 \pm 0.10$, with an average distance between SNP pairs of $255.8 \mathrm{~kb}$.

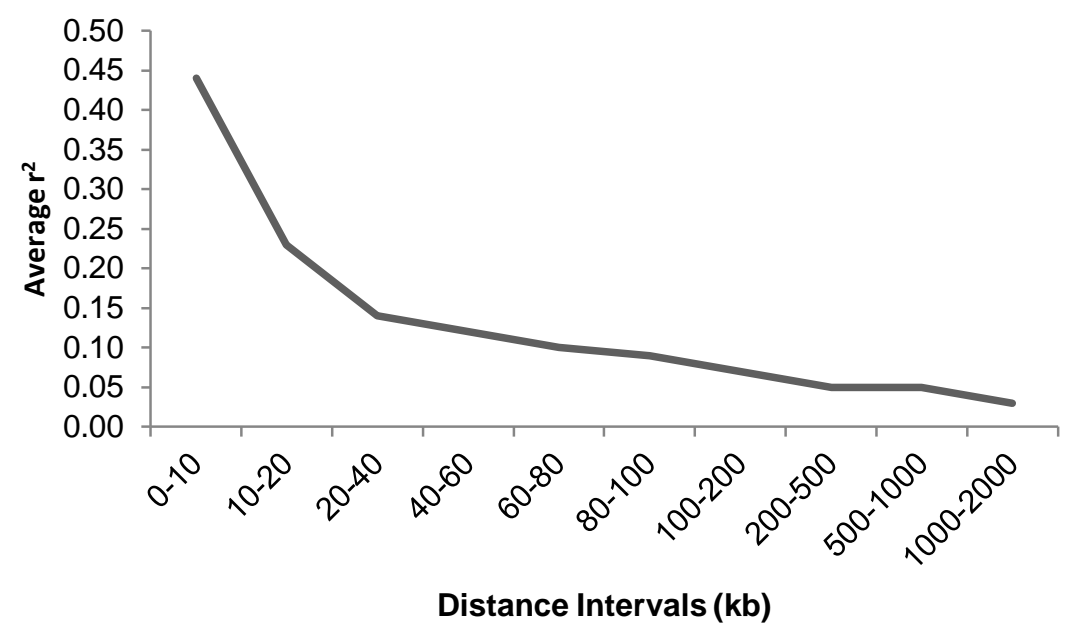

Figure 2 Average $\mathrm{r}^{2}$ values at given distances $(\mathrm{kb})$ for Tswana goat population 
A graphic representation of the effective population size at each point from 900 to 13 generation ago is given in Figure 3. The results show a progressive decrease in Ne over time with an estimation of 266 animals at 13 generations ago.

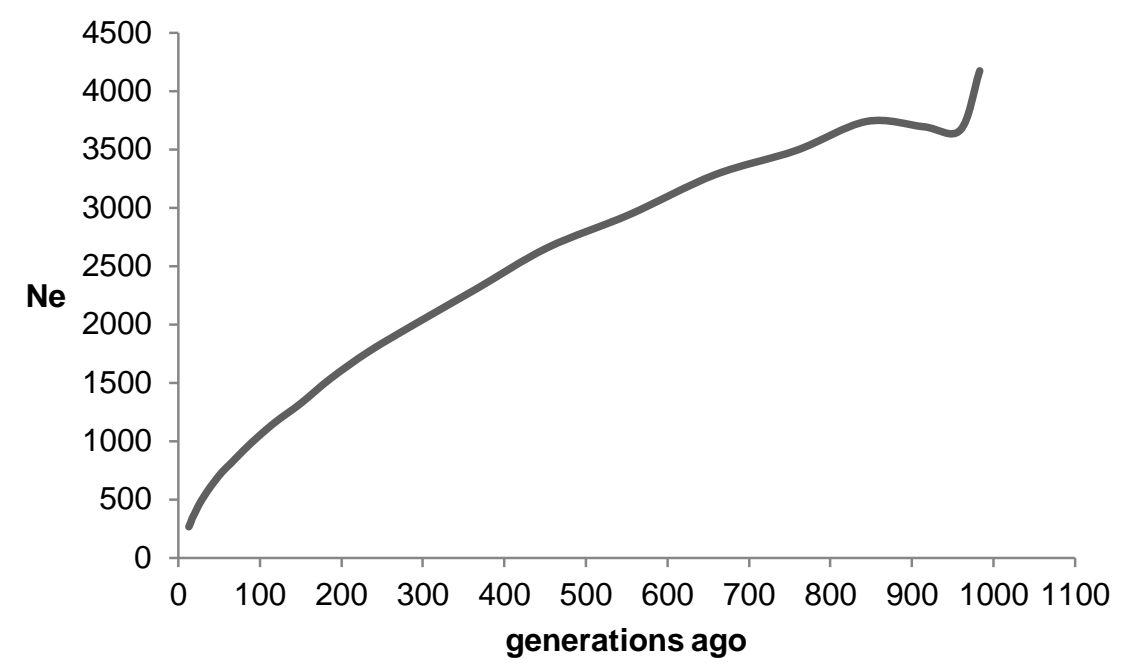

Figure 3 Average effective population size for central region Tswana goats, from 900 to 13 generations ago. Ne: Effective population size

\section{Discussion}

Indigenous goats are valuable genetic resources, particularly for resource-poor smallholder farmers, owing to their ability to thrive in diverse geographical environments with limited inputs (Huson et al., 2014). The flock structure of the indigenous population indicated that the flocks generally consist of mostly female animals. Farmers prefer to sell males for income, slaughter them for home consumption, or give them as gifts (Monau et al., 2017). Mdladla et al. (2017) reported a similar observation in various provinces of South Africa. Additionally, farmers prefer to keep exotic bucks such as Boer goats for crossbreeding, which contributed to lower numbers of young (i.e. 0-14 and 15-23 months) indigenous goats being kept. This is in contrast with a previous study, which reported a significant number of indigenous Tswana males of 0-12 months in the flocks (Nsoso et al., 2004). A decrease in the number of indigenous breeding bucks is one of the factors that threaten the existence of an indigenous breed (Mandal et al., 2014). Tswana goats could be endangered or vulnerable, and it is important to strategize and conserve indigenous Tswana goats for sustainable utilization and future breeding programmes.

Peculiar morphological characteristics of Tswana goats include a mixture of coat colour patterns and the presence of horns and beards (Katangole et al., 1996). Farmers could unintentionally be selecting towards these traits as an environmental adaptation mechanism for thermoregulation and predation. Predation is one of the major constraints affecting goat production in Botswana (Monau et al., 2017), and animals use their horns for protection, while mixed coat colour patterns act as camouflage (Hagan et al., 2012). Coat colour is also useful in protecting deep tissue against excess exposure to solar shortwave radiation in tropical zones (Castanheira et al., 2010). The predominant mixed coat colour could be an advantage during the common seasonal temperature fluctuations in the country. The presence of beards is perceived to be associated with superior reproductive traits such as high conception, high prolificacy and high fertility rates (Gatew et al., 2015). Large-scale studies are needed to establish the true effect of these qualitative traits on adaptation, performance and the overall productivity of Tswana goats.

Bodyweight and body sizes of Tswana goat have decreased compared with the previous report (Nsoso et al., 2004). Nsoso and colleagues (2004) reported an average BW of $41.7 \pm 0.5 \mathrm{~kg}$ and heart girth of $80.5 \pm 0.3$ in mature (>36 months) female Tswana goats. The difference could be due to a lack of availability of feed resources inequality and quantity. The current survey was undertaken during drought and there were substantial shortages of feed and water that could have major impacts on physical growth of animals. However, the indigenous mature Tswana goats had superior performance in terms of BW and body measurements compared with other indigenous goat breeds in South Africa (BW: $28.96 \pm 0.37 \mathrm{~kg}, \mathrm{BL}: 60.85$ 
$\pm 0.29 \mathrm{~cm}$ ) (Selolo et al., 2015) and Tanzania (BW $=28.97 \pm 0.52 \mathrm{~kg}, \mathrm{BL}=51.60 \pm 0.40 \mathrm{~cm}$ ) (Nguluma et al., 2016). More studies on the effect of vegetation on performance should be performed for comparison in and across agro-ecological regions.

The availability of SNP arrays provides an opportunity to investigate current genetic structure and diversity of livestock for effective selection and conservation strategies (Groeneveld et al., 2010). This study is the first attempt to genetically characterize the indigenous Tswana goat, using genome-wide SNP markers. The overall informative SNPs (92.5\%) observed in the current study were higher than those reported by Lashmar et al. (2015) on Angora goats (82\%) and Mdlala et al. (2016) on various South African indigenous goat breeds (87.1\%), but comparable with Lashmar et al. (2016) on dairy goats (92.3\%). The variation could be attributed to the threshold applied during QC. For instance, a SNP call rate of $98 \%$ was used for Angora goats (Lashmar et al., 2015) whilst in this study a SNP call rate of $97 \%$ was used. The results indicate, however, that the SNP chip could be used successfully for genomic studies on indigenous goats.

The results revealed high levels of genetic diversity (0.423) which is comparable with estimates by Kim et al. (2016) on the indigenous Barki goats (0.40) of Egypt and by Mdladla et al. (2016) on South African indigenous goats (0.41). Indigenous goats kept under communal systems are exposed to natural selection, where animals become genetically adapted for survival in their natural environments, while maintaining high within and between population genetic variability (Kim et al., 2016). Previous studies noted that the goat ancestor (bezoar) had broad genetic diversity, which has been conveyed to the modern goat, which has not undergone intensive selection, as has been experienced in species such as cattle (Gerbault et al., 2012).

Individual inbreeding coefficient estimates in this study were lower than the estimates reported $(0.12 \pm$ 0.16) by Maletsanake et al. (2013) using microsatellite markers on a Tswana goat population kept at an experimental farm under a controlled breeding programme. The difference could be because the samples in this study were drawn from a large population of communal areas, and care was taken to select unrelated individuals.

Principal component analysis revealed that most animals in the central region were clustered, with a few outliers. The reason for few outliers could be lack of selection and uncontrolled breeding practised in communal management systems. The low value of cross validation $(K=1)$ in this study is similar to the report of Kominakis et al. (2017) in Frizarta sheep. This indicates that there is no genetic differentiation or inferred clusters in the population. However, a more extensive sampling of Tswana goats covering various geographical regions of Botswana is necessary to assess the demographic history and relationship of individuals.

The average LD $(0.067 \pm 0.10)$ reported in this study is slightly lower than the report of Mdladla et al. (2015), which reported values of $0.09 \pm 0.12$ on Zulu, Venda and Xhosa and $0.11 \pm 0.14$ on South African Tswana goats. LD values, however, are influenced by factors such as history and structure of the population, sample size and strictness of SNP filtering (i.e. threshold of MAF and HWE) (Bohmanova et al., 2011). Khatkar et al. (2008) pointed out that studies with relatively small sample sizes are subject to bias and loss of accuracy. This bias may vary with inter-marker distance. Therefore, it would be interesting to confirm the LD results in this investigation with a larger number of genotyped animals.

The pattern of LD decay with distance in this population is consistent with the report of Brito et al. (2015) on various breeds of goats. Compared with other indigenous species, linkage disequilibrium declined more slowly in the indigenous Tswana goat population than in the indigenous cattle population studied by Makina et al. (2014). The low level of long range LD indicates lack of selection on the population or large effective population size in the recent past (Brito et al., 2015). The persistence of LD over short distances, however, indicates that more markers will be needed to obtain the same power to detect association (Meadows et al., 2008). LD decay determines the power of QTL detection in association mapping studies and helps to determine the number of markers required for successful association mapping and genomic selection (Mastrangelo et al., 2014). Meuwissen et al. (2001) and Qanbari et al. (2010) proposed an $r^{2}$ value of $\geq 0.2$ as being useful for association studies. Further advancement on dense SNP panel for goats would be essential for high power association mapping and genomic selection efficiency in future breeding programmes of Tswana goats.

The observed values of $\mathrm{Ne}$ in this study were consistent with the report of Mdladla et al. (2015) for South African ecotypes. Large effective population size is mostly correlated with natural selection and multiple breeding objectives (Meuwissen \& Woolliams, 1994), which are the basic characteristics of smallholder communal goat production (Monau et al., 2017). It is important to manage this effective population size to preserve genetic variability in the indigenous Tswana goat population for optimal utilization and sustainable development programmes. 


\section{Conclusions}

Tswana goats possess environmental adaptive traits such as the presence of horns and beards, and mixed coat colour, and exhibit a relatively high level of genetic diversity and a large effective population size that can be exploited for future breed improvement. These are the first genomic data for the Tswana goat and could be used as a benchmark for further investigations. Further studies should be performed to characterize a larger proportion of the indigenous Tswana goat breed genetically for improved food security and increased productivity to benefit resource-poor farmers.

\section{Acknowledgements}

The authors would like to acknowledge Botswana University of Agriculture and Natural resources (BUAN) and Organisation of Women in Science for the Developing World (OSWD) for financial assistance. Sincere gratitude goes to the farmers of the regions for the unreserved support and cooperation.

\section{Authors' Contributions}

PIM and EMK conceived the study. PIM was the lead researcher performing data collection, data analyses, result interpretation and wrote the manuscript (as part of her PhD programme). CV, EMK \& SJN provided guidance and assisted with revision of the manuscript.

\section{Conflict of Interest Declaration}

The authors declare that they have no conflict of interest.

\section{References}

Alexander, D.H., Novembre, J. \& Lange, K., 2009. Fast model-based estimation of ancestry in unrelated individuals. Genome Res. 19, 1655-1664.

Barbato, M., Orozco-terWengel, P., Tapio, M. \& Bruford, M.W., 2015. SNeP: A tool to estimate trends in recent effective population size trajectories using genome-wide SNP data. Front. Genet. 6,109-122.

Blasco, A. \& Toro, M.A., 2014. A short critical history of the application of genomics to animal breeding. Livest. Sci. 166, 4-9

Bohmanova, J., Sargolzaei, M. \& Schenkel, F.S., 2010. Characteristics of linkage disequilibrium in North American Holsteins. BMC Genom. 11, 421-432.

Brito, L.F., Jafarikia, M., Grossi, D.A., Kijas, J.W., Porto-Neto, L.R., Ventura, R.V., Salgorzaei, M. \& Schenkel, F.S., 2015. Characterization of linkage disequilibrium, consistency of gametic phase and admixture in Australian and Canadian goats. BMC Genet.16, 67-82.

Castanheira, M., Paiva, S.R. Louvandini, H., Landim, A., Fiorvanti, M.C.S. Dallago, B.S., Correa, P.S. \& McManus, C., 2010. Use of heat tolerance traits in discriminating between groups of sheep in central Brazil. Trop. Anim. Health Prod. 42, 1821-1828.

Corbin, L.J., Blott, S.C., Swinburne, J.E., Vaudin, M., Bishop, S.C. \& Woolliams, J.A., 2010. Linkage disequilibrium and historical effective population size in the thoroughbred horse. Anim. Genet. 41, 8-15.

Els, F., Kotze, J.A. \& Swart, H., 2004. Genetic diversity of indigenous goats in Namibia using microsatellite markers: Preliminary results. S. Afr. J. Anim. Sci. 34 (Supplement 2), 65-67.

FAO, 2012. Phenotypic characterization of animal genetic resources. FAO Animal Production and Health Guidelines No.11. FAO, Rome, Italy.

Garrine, C.M.L.P., 2007. Genetic characterization of indigenous goat populations of Mozambique. MSc thesis, Department of Production Animal Studies, Faculty of Veterinary Science, University of Pretoria.

Gatew H., Hassen, H. Kebede K., Haile, A., Lobo, R.N.B., Yetayew, A. \& Rischkowsky, B., 2015. Characterisation of indigenous goat populations in selected areas of Ethiopia, Am.-Eurasian J. Sci. Res. 10, 287-298.

Gerbault, P., Powell, A. \& Thomas, M.G., 2012. Evaluating demographic models for goat domestication using mtDNA sequences. Anthropozoologica 47, 65-78.

Groeneveld, L.F., Lenstra, J.A., Eding, H., Toro, M.A., Scherf, B., Pilling, D., Negrini, R., Finlay, E.K., Jianlin, H., Groeneveld, E. \& Weigend, S. The GLOBALDIV Consortium, 2010. Genetic diversity in farm animals - A review. Anim. Genet. 41, 6-31.

Hagan, J.K., Apori, S.O., Bosompem, M., Ankobea, G. \& Mawuli, A. 2012. Morphological characteristics of indigenous goats in the coastal savannah and forest eco-zones of Ghana. J. Anim. Sci. Adv. 2, 813-821.

Huson, H., Sonstegard, T., Silverstein, J., Woodward-Greene, M., Masiga, C., Muchadeyi, F. et al., 2014. Genetic and phenotypic characterization of African goat populations to prioritize conservation and production efforts for smallholder farmers in sub-Saharan Africa. Vancouver, Canada: 10th World Congress on Genetics Applied to Livestock Production, 2014.

Katongole, J.B.D., Sebolai, B. \& Madimabe, M.J., 1996. Morphological characterization of the Tswana goat. In: S.H.B Lebbie \& E. Kagwani (eds). Small ruminant research and development in Africa. Proc. 3rd Biennial Conference of the African Small Ruminant Research Network, UICC, Kampala, Uganda, 5-9 December 1994. pp. 43-46.

Khanyile, K.S., Dzomba, E.F. \& Muchadeyi, F.C., 2015. Population genetic structure, linkage disequilibrium and effective population size of conserved and extensively raised village chicken populations of Southern Africa. Front. Genet. 6, 13-24. 
Khatkar, M.S., Nicholas, F.W., Collins, A.R., Zenger, K.R., Cavanagh, J.A., Barris, W., Schnabel, R.D., Taylor, J.F. \& Raadsma, H.W., 2008. Extent of genome-wide linkage disequilibrium in Australian Holstein-Friesian cattle based on a high-density SNP panel. BMC Genom. 9, 187-220.

Kim, E.S., Elbeltagy, A.R., Aboul-Naga, A.M., Rischkowsky, B., Sayre, B., Mwacharo, J.M. \& Rothschild, M.F., 2016. Multiple genomic signatures of selection in goats and sheep indigenous to a hot arid environment. Hered. 116, 255-264.

Kominakis, A., Hager-Theodorides, A.L., Saridaki, A., Antonakos, G. \& Tsiamis, G., 2017. Genome-wide population structure and evolutionary history of the Frizarta dairy sheep. Animal 11, 11680-1688.

Lashmar, S.F., Visser, C. \& Van Marle-Köster, E., 2015. Validation of the 50K Illumina goat SNP chip in the South African Angora goat. S. Afr. J. Anim. Sci. 45, 56-59.

Lashmar, S.F., Visser, C. \& Van Marle-Köster, E., 2016. SNP-based genetic diversity of South African commercial dairy and fiber goat breeds. Small Rumin. Res. 136, 65-71.

Lin, B.Z., Sasazaki, S. \& Mannen, H., 2010. Genetic diversity and structure in Bos Taurus and Bos indicus populations analyzed by SNP markers. Anim. Sci. J. 81, 281-289.

Madubi, M., Kifaro, G. \& Petersen, P., 2000. Phenotypic characterization of three strains of indigenous goats in Tanzania. Anim. Gen. Res. Info. 28, 43-51.

Makhabu, S.W., Marotsi, B. \& Perkins, J., 2002. Vegetation gradients around artificial water points in the central Kalahari game reserve of Botswana. Afr. J. Ecol. 40, 103-109.

Makina, S.O., Muchadeyi, F.C., Van Marle-Köster, E., MacNeil, M.D. \& Maiwashe, A., 2014. Genetic diversity and population structure among six cattle breeds in South Africa using a whole genome SNP panel. Front. Genet. 5, 333-356.

Maletsanake, D., Nsoso, S.J. \& Kgwatalala, P.M., 2013. Genetic variation from 12 microsatellite makers in an indigenous Tswana goat flocks in south-eastern Botswana. Livest. Res. Rural Dev. 25, 21. Available at: http://www.Irrd.org//rrd25/2/male25021.htm Retrieved 5.April, 2018.

Mandal, A., Karunakaran, M., Rout, P.K. \& Roy, R., 2014. Conservation of threatened goat breeds in India. Anim. Genet. Resour. 55, 47-55.

Mastrangelo, S., DiGerlando, R., Tolone, M., Tortorici, L., Sardina, M.T. \& Portolano, B., 2014. International Sheep Genomics Consortium. Genome wide linkage disequilibrium and genetic structure in Sicilian dairy sheep breeds. BMC Genet. 15, 108.

Mdladla, K., Dzomba, E.F., Huson, H.J. \& Muchadeyi, F.C., 2016. Population genomic structure and linkage disequilibrium analysis of South African goat breeds using genome-wide SNP data. Anim. Genet. 47, 471-482.

Mdladla, K., Dzomba, E.F. \& Muchadeyi, F.C., 2017.Characterization of the village goat production systems in the rural communities of the Eastern Cape, KwaZulu-Natal, Limpopo and North West Provinces of South Africa. Trop. Anim. Health Prod. 49, 515-527.

Meadows, J., Chan, E. \& Kijas, J., 2008. Linkage disequilibrium compared between five populations of domestic sheep. BMC Genet. 9, 61-87.

Meuwissen, T.H.E. \& Woolliams, J.A., 1994. Effective sizes of livestock populations to prevent a decline in fitness. Theor. Appl. Genet. 89, 1019-1026.

Meuwissen, T.H.E., Hayes, B.J. \& Goddard, M.E., 2001. Prediction of total genetic value using genome-wide dense marker maps. Genet. 157, 1819-1829.

Mogotsi, K., Nyangito, M.M. \& Nyariki, D.M., 2011. Drought management strategies among agro-pastoral communities in non-equilibrium Kalahari ecosystems. Environ. Res. 5, 156-162.

Mogotsi, K., Nyangito, M.M. \& Nyariki, D.M., 2013. The role of drought among agro-pastoral communities in a semi-arid environment: The case of Botswana. J. Arid Environ. 91, 38-44.

Monau, P. I., Visser, C., Nsoso, S.J. \& Van Marle-Koster, E., 2017. A survey analysis of indigenous goat production in communal farming systems of Botswana. Trop. Anim. Health Prod. 49, 1265-1271.

Msanga, Y.N., Mwakilembe, P.L. \& Sendalo, D., 2012. The indigenous cattle of the Southern Highlands of Tanzania: Distinct phenotypic features, performance and uses. Livest. Res. Rural Dev. 110, 1-24

Nguluma, A.S., Msalya, G. \& Chenyambuga, S.W., 2016. Phenotypic variation among four populations of small East African goats of Tanzania. Livest. Res. Rural Dev. 28 (136). Available at: http://www.Irrd.org/lrrd28/8/ngul28136.html. Accessed 4 April 2018

Nguluma, A.S., Huang, Y., Zhao, Y., Chen, L., Msalya, G., Lyimo, C., Guangxin, E. \& Chenyambuga, S.W., 2018. Assessment of genetic variation among four populations of Small East African goats using microsatellite markers. S. Afr. J. Anim. Sci. 48, 117-127

Nsoso, S.J., Podisi, B., Otsogile, E., Mokhutshwane, B.S. \& Ahmadu, B., 2004. Phenotypic characterization of indigenous Tswana goats and sheep breeds in Botswana: Continuous traits. Trop. Anim. Health Prod. 36, 789-800.

Pace, J.E. \& Wakeman, D.L., 2003. Determining the age of cattle by their teeth. Institute of Food and Agricultural Sciences, University of Florida, USA. Available at http://edis.ifas.ufl.edu/AN046.

Pieters, A., Van Marle-Köster, E., Visser, C. \& Kotze, A., 2009. South African developed meat type goats: A forgotten animal genetic resource? Anim. Gen. Res. Info. 44, 33-43.

Purcell, S., Neale, B., Todd-Brown, K., Thomas, L., Ferreira, M.A., Bender, D., Maller, J., Sklar, P., De Bakker, P.I., Daly, M.J. \& Sham, P.C., 2007. PLINK: A tool set for whole-genome association and population-based linkage analyses. Am. J. Hum. Genet. 81, 559-575.

Qanbari, S., Pimentel E., Tetens J., Thaller, G., Lichtner, P., Sharifi, A. \& Simianer, H., 2010. The pattern of linkage disequilibrium in German Holstein cattle. Anim. Genet. 41, 346-356. 
Rischkowsky, B., Pilling, D. \& Scherf, B., 2007. Status of animal genetic resources. In: B. Rischkowsky \& D. Pilling (eds). Part 1: The state of agricultural biodiversity in the livestock sector - The state of the world's animal genetic resources for food and agriculture (pp. 23-49). Commission on Genetic Resources for Food \& Agriculture, FAO, Rome.

Selolo, T.C., Mashiloane, M.L., Norris, D., Ng'ambi, J.W. \& Brown, D., 2015. Morphological differentiation of indigenous goats in different agro-ecological zones of Vhembe District, Limpopo Province, South Africa. Indian J. Anim. Res. 49, 527-531.

Singh, U., Deb, R., Alyethodi, R.R., Alex, R., Kumar, S., Chakraborty, S., Dhama, K. \& Sharma, A., 2014. Molecular markers and their applications in cattle genetic research: A review. BGM 6, 49-58.

Sölkner, J., Nakimbugwe, H. \& Valle, Z.A., 1998. Analysis of determinants for success and failure of village breeding programmes. In: Proceedings of the Sixth World Congress on Genetics applied to Livestock Production, vol. 25, Armidale, NSW, Australia, 11-16 January 1998. pp. 273-280.

SAS Institute, 2009. Statistical Analysis Systems (SAS 9.3) Qualification tools user's guide. SAS Institute Inc: Cary N.C., USA.

Statistics Botswana, 2015. Annual Agricultural Survey Report of 2013. Gaborone, Botswana. Available at www.statsbots.org.bw.

Tosser-Klopp, G., Bardou, P., Bouchez, O., Cabau, C., Crooijmans, R., Dong, Y., Donnadieu-Tonon, C., Eggen, A., Heuven, H.C., Jamli, S. \& Jiken, A.J., 2014. Design and characterization of a 52K SNP chip for goats. PloS One 9(1). https://journals.plos.org/plosone/article?id=10.1371/journal.pone.0086227.

Van Marle-Köster, E., Visser, C., Makgahlela, M. \& Cloete, S.W.P., 2015. Genomic technologies for food security. A review of challenges and opportunities in southern Africa. Food Res. Int. 76, 971-979.

Yang, J., Lee, S.H., Goddard, M.E. \& Visscher, P.M., 2011. GCTA: A tool for genome-wide complex trait analysis. Am. J. Hum. Genet. 88, 76-82. 